\title{
FUNGSI BARIER KULIT PADA PASIEN MELASMA
}

\author{
Syamsinar, Niken Kusumaningrum, Sri Awalia Febriana, Dwi Retno Adi Winarni \\ Bagian Ilmu Kesehatan Kulit dan Kelamin, \\ FK Universitas Gadjah Mada - RSUP Dr. Sardjito, Yogyakarta
}

\begin{abstract}
ABSTRAK
Keratinocyte derived factor dianggap berperan dalam menstimulasi proses pigmentasi pada melasma sebagai respons terhadap adanya gangguan barier kulit akibat paparan radiasi ultraviolet. Penelitian ini bertujuan untuk menganalisis perbedaan fungsi barier antara kulit lesi dengan kulit normal perilesi dan korelasi antara fungsi barier kulit lesi dengan skor Melasma Area Severity Index (MASI) pada pasien melasma.

Penelitian ini merupakan penelitian analitik observasional dengan rancangan potong lintang. Pengukuran transepidermal water loss (TEWL), kadar sebum, hidrasi dan $p H$ kulit dilakukan pada 32 subyek yang memenuhi kriteria. Perbedaan fungsi barier antara kulit lesi dengan kulit normal perilesi dianalisis dengan uji-t berpasangan, kecuali kadar sebum menggunakan uji Wilcoxon. Korelasi antara fungsi barier kulit lesi dengan skor MASI dianalisis dengan korelasi Pearson, kecuali kadar sebum menggunakan korelasi Spearman.

Hasil penelitian ini berupa nilai TEWL, kadar sebum, dan pH kulit menunjukkan perbedaan yang bermakna $(p<0,05)$. Sebaliknya dengan hidrasi kulit tidak terdapat perbedaan yang bermakna antara kulit lesi dibandingkan kulit normal perilesi $(p>0,05)$. Tidak terdapat korelasi yang bermakna antara fungsi barier kulit baik berdasarkan nilai TEWL, kadar sebum, hidrasi maupun $p H$ kulit dengan skor MASI $(p>0,05)$. Kesimpulan penelitian ini adalah terdapat perbedaan fungsi barier berdasarkan nilai TEWL, kadar sebum, dan pH kulit, namun tidak terdapat perbedaan fungsi barier berdasarkan hidrasi kulit antara kulit lesi dengan kulit normal perilesi pada pasien melasma. Tidak terdapat korelasi antara fungsi barier kulit lesi dengan skor MASI pada pasien melasma.
\end{abstract}

Kata kunci: melasma, pigmentasi, fungsi barier, skor MASI, TEWL, hidrasi kulit, kadar sebum, pH kulit

\section{SKIN BARRIER FUNCTION IN MELASMA PATIENT}

\section{ABSTRACT}

Keratinocyte derived factor considered to play a role in stimulating skin pigmentation process in melasma as response to dysfunction of skin barrier due ultraviolet radiation exposure. The purpose of this study is to analyse the difference of barrier function in lesional skin, and perilesional normal skin and the correlation of skin barrier function of the lesional skin with Melasma Area Severity Index (MASI) score in melasma patient.

This study is an observational analytic study with cross sectional design. Measurement of transepidermal water loss (TEWL), sebum levels, hydration and $p H$ of the skin is done in 32 subjects who meet the criteria. The difference between the barrier function of lesional skin with perilesional normal skin analyzed by paired t-test, except sebum levels using the Wilcoxon test. The correlation between barrier function of the lesional skin with MASI score, analysis was done by Pearson correlation, except the level of sebum which use Spearman correlation.

The result of this study indicate TEWL value, sebum levels, and skin $p H$ showing significant difference (p $<0,05)$, contrary to skin hydration no significant difference between lesional skin and perilesional normal skin $(p>0.05)$. There was no significant correlation between skin barrier function either by TEWL values, the levels of sebum, hydration and $\mathrm{pH}$ of the skin with MASI scores $(p>0.05)$. It is concluded that there are differences in barrier function based on the value of TEWL, sebum levels, and $p H$ of the skin, but there was no difference by hydration of the skin barrier function of lesional skin with perilesionalnormal skin in patients with melasma.

Keywords: melasma, pigmentation, skin barrier function, MASI score, TEWL, skin hydration, sebum level, skin $\mathrm{pH}$

Korespondensi:

Gedung Radiopoetro, 1t.3.

Jl. Farmako, Sekip. Yogyakarta

Telp/Fax: $0274-560700$

Email: syamsinar.danar12345@gmail.com 


\section{PENDAHULUAN}

Melasma merupakan kelainan kulit yang dipengaruhi oleh interaksi lingkungan dan hormonal pada individu yang memiliki suseptibilitas secara genetik. ${ }^{1}$ Kelainan ini berupa lesi makula atau bercak hiperpigmentasi, tepi iregular, berbatas tegas, dan simetris, mengenai area tubuh yang terpapar sinar matahari terutama wajah. ${ }^{2-5}$ Kasus melasma dijumpai pada lebih dari 5 juta orang di Amerika Serikat, sedangkan di Asia Tenggara sekitar 2,5-4\% dari seluruh pasien yang berobat ke klinik dermatologi. ${ }^{6}$

Kulit merupakan organ kompleks yang menutupi seluruh permukaan tubuh dan barier yang mampu beradaptasi terhadap pengaruh lingkungan. ${ }^{7,8}$ Paparan radiasi ultraviolet (UV) dapat menyebabkan stres pada barier kulit. ${ }^{9-11}$ Keratinosit merupakan sel yang sangat berperan pada pembentukan dan pemeliharaan lapisan barier kulit. ${ }^{12}$ Beberapa keratinocyte derived factor (KDF) dianggap berperan dalam menstimulasi proses pigmentasi sebagai respons terhadap stres pada barier akibat adanya stresor eksternal berupa paparan radiasi UV-B., ${ }^{9} 10,13-16$

Pada pasien melasma beberapa ekspresi KDF ditemukan meningkat pada kulit lesi dibandingkan kulit normal perilesi. ${ }^{9}{ }^{17-19}$ Peningkatan ekspresi ini diduga sebagai respons keratinosit terhadap gangguan fungsi barier kulit yang disebabkan adanya stresor eksternal berupa paparan radiasi UV., ${ }^{2,10}$ Pemahaman menyeluruh terkait etiologi dan patogenesis melasma pada khususnya, serta kelainan hiperpigmentasi pada umumnya, sangat penting pada tata laksana melasma. ${ }^{9}$

Berbagai penelitian mengenai peran barier kulit pada etiopatogenesis melasma telah mulai dilakukan dengan hasil yang bervariasi..$^{20-22}$ Berdasarkan penjelasan tersebut di atas, pembuktian hubungan fungsi barier kulit terhadap kejadian melasma menjadi hal yang menarik untuk diteliti. Penelitian ini bertujuan untuk menganalisis perbedaan fungsi barier antara kulit lesi dengan kulit normal perilesi dan korelasi antara fungsi barier kulit lesi dengan skor melasma area severity index (MASI) pada pasien melasma.

\section{METODE DAN CARA PENELITIAN}

Penelitian ini merupakan suatu penelitian analitik observasional dengan menggunakan rancangan penelitian potong lintang (cross sectional). Subyek penelitian ini adalah pasien melasma sebanyak 32 orang yang bersedia secara sukarela mengikuti penelitian dan memenuhi kriteria inklusi. Pengambilan sampel dilakukan dengan cara consecutive sampling. Penelitian ini telah memperoleh kelaikan etik dari Medical and Health Research Ethics Committee (MHREC) Fakultas Kedokteran Universitas Gadjah Mada, Yogyakarta.

Pengukuran parameter fungsi barier kulit dilakukan setelah periode aklimatisasi oleh petugas yang sama. Lesi hiperpigmentasi tergelap pada tiap area wajah diukur indeks melanin dengan menggunakan Mexameter ${ }^{\circledR}$. Indeks melanin lesi hiperpigmentasi tergelap dengan tertinggi ditentukan sebagai kulit lesi, dan kulit tanpa hiperpigmentasi disekelilingnya yang berjarak sekitar $0,5 \mathrm{~cm}$ dari kulit lesi ditentukan sebagai kulit normal perilesi. Fungsi barier kulit lesi dan kulit normal perilesi dinilai dengan mengukur nilai TEWL, kadar sebum, hidrasi dan pH kulit.

Analisis statistik terhadap fungsi barier berdasarkan nilai TEWL, hidrasi dan $\mathrm{pH}$ kulit dilakukan dengan menggunakan parametrik, uji-t berpasangan. Fungsi barier berdasarkan kadar sebum menggunakan uji Wilcoxon, karena data kedua kelompok tidak terdistribusi normal. Kesesuaian inter-observer dianalisis dengan uji Bland Altman karena data skor MASI berupa data numerik. Korelasi antara fungsi barier kulit dengan skor MASI di analisis dengan korelasi Pearson, kecuali kadar sebum menggunakan korelasi Spearman, karena data kedua kelompok tidak terdistribusi normal. Kemaknaan didapat dengan melihat nilai $\mathrm{p}<0,05$.

\section{HASIL PENELITIAN}

Semua subyek dalam penelitian ini berjenis kelamin perempuan. Rentang usia subyek saat mengikuti penelitian antara 36-55 tahun, dengan usia rerata subyek dalam penelitian ini adalah 46,88 tahun. Pekerjaan subyek terbanyak adalah ibu rumah tangga yaitu $28,1 \%$. Pendidikan terakhir paling banyak adalah SMA atau sederajat yaitu $37,5 \%$. Sebagian besar subjek memiliki tipe kulit IV (71,9\%), dengan riwayat keluarga juga menderita melasma $(65,6 \%)$ dan rerata durasi penyakit 7,8 tahun. Separuh dari subyek penelitian menggunakan alat kontrasepsi, terbanyak berupa intra uterine device (IUD) sebanyak $31,2 \%$, diikuti kontrasepsi suntik $(12,5 \%)$ dan kontrasepsi oral $(6,3 \%)$. Tipe melasma terbanyak adalah tipe sentrofasial yaitu $87,5 \%$, diikuti tipe malar $12,5 \%$. Tidak didapatkan subyek dengan tipe mandibular.

Rerata selisih inter-observer 0,1188 , nilai $\mathrm{p}=0,691$, dan limit of agreement minimal rerata selisih $-3,16$ dan maksimal rerata selisih 3,39, sehingga dapat disimpulkan bahwa inter-observer mempunyai kesesuaian atau reliabilitas yang baik. Rerata nilai TEWL dan $\mathrm{pH}$ kulit lesi lebih tinggi dibandingkan dengan kulit normal perilesi, serta menunjukkan perbedaan yang bermakna dengan nilai p masing-masing 0,002 dan 0,014 (gambar 1). 


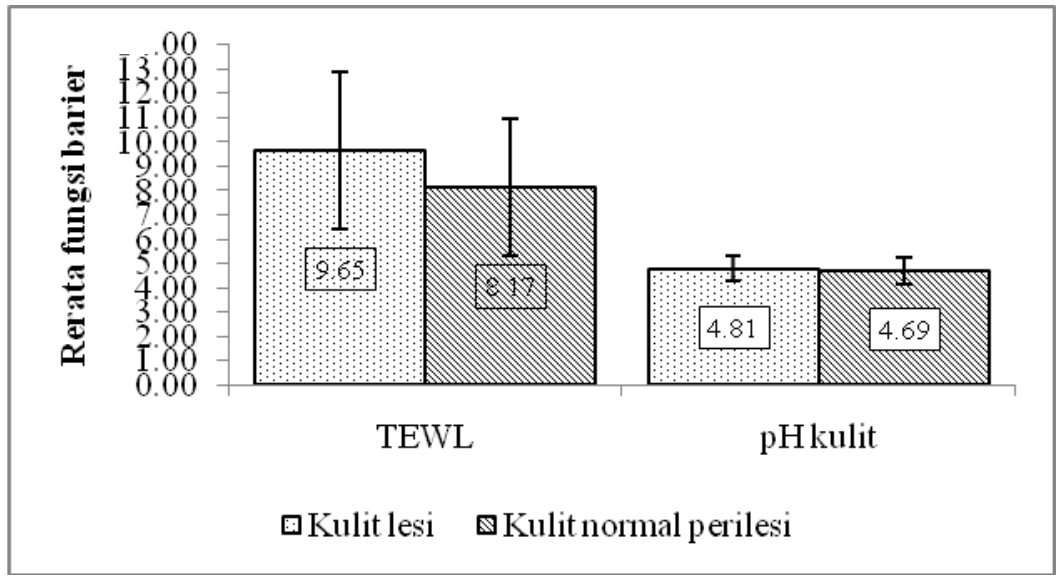

Nilai TEWL dan $\mathrm{pH}$ kulit lesi berbeda bermakna secara statistik $\mathrm{p}<0,05$ dibandingkan kulit normal perilesi (uji t berpasangan)

Gambar 1. Perbandingan rerata nilai TEWL dan $\mathrm{pH}$ kulit lesi dengan kulit normal perilesi pada pasien melasma.

Rerata kadar sebum kulit lesi lebih rendah dibandingkan dengan kulit normal perilesi dan menunjukkan perbedaan yang bermakna dengan nilai $\mathrm{p}=0,000$.
Rerata nilai hidrasi kulit lesi lebih rendah dibandingkan dengan kulit normal perilesi dan tidak menunjukkan perbedaan yang bermakna dengan nilai $\mathrm{p}<0,689$ (gambar 2).

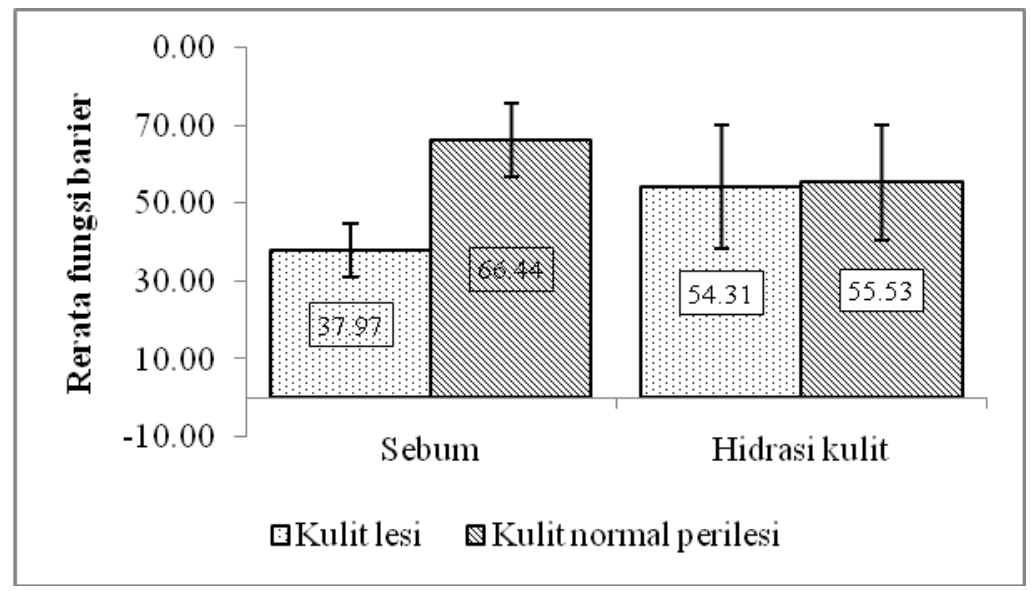

Kadar sebum berbeda bermakna secara statistik $\mathrm{p}<0,05$ dan nilai hidrasi kulit tidak bermakna secara statistik $\mathrm{p}>0,05$ dibandingkan kulit normal perilesi (kadar sebum : uji Wilcoxon; hidrasi kulit : uji t berpasangan).

Gambar 2. Perbandingan rerata kadar sebum dan hidrasi kulit lesi dengan kulit normal perilesi pada pasien melasma. 
Tidak terdapat korelasi yang bermakna antara fungsi barier kulit lesi baik berdasarkan nilai TEWL $(\mathrm{p}=0,127)$, kadar sebum ( $\mathrm{p}=0,588)$, hidrasi kulit $(\mathrm{p}=0,394)$, maupun $\mathrm{pH}$ kulit $(\mathrm{p}=0,590)$ dengan skor MASI (gambar 3$)$.

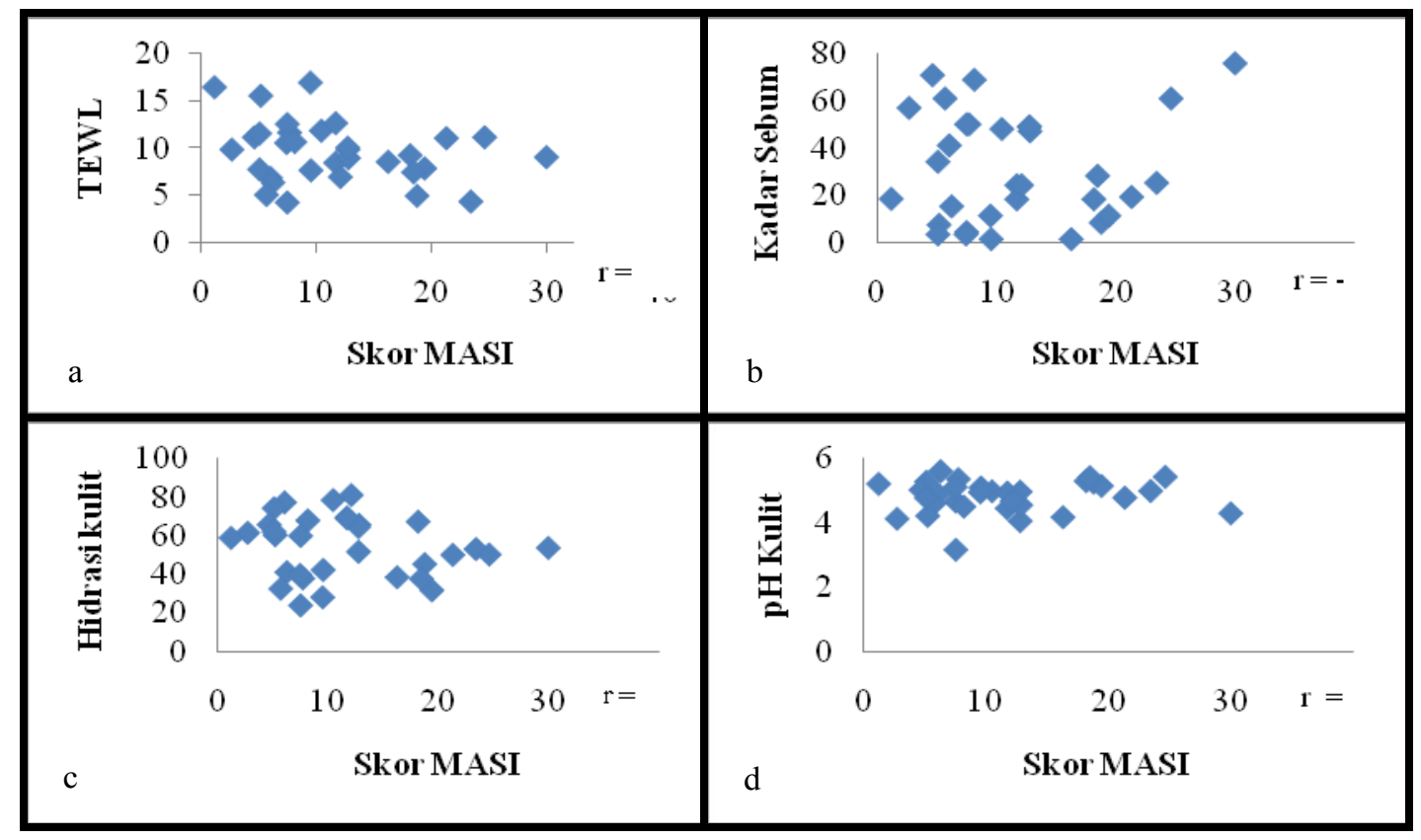

Gambar 3. Korelasi antara fungsi barier kulit lesi berdasarkan (a) nilai TEWL; (b) kadar sebum; (c) hidrasi kulit; (d) pH kulit dengan skor MASI.

\section{PEMBAHASAN}

Karakteristik subyek pada penelitian ini menunjukkan tipe sentrofasial merupakan tipe melasma terbanyak $(87,5 \%)$ diikuti tipe malar $(12,5 \%)$, hal ini sesuai dengan penelitian sebelumnya yang melaporkan bahwa tipe melasma terbanyak adalah tipe sentrofasial diikuti tipe malar dan mandibular. ${ }^{23,24}$ Melasma tipe sentrofasial paling sering dijumpai khususnya pada perempuan, sedangkan tipe malar lebih sering dijumpai pada laki-laki. Hal ini diduga berkaitan dengan aktivitas pekerjaan yang dominan di luar rumah pada pasien melasma laki-laki. ${ }^{3,25}$

Beberapa penelitian menunjukkan tipe kulit terbanyak yang menderita melasma adalah tipe kulit IV yaitu $38,4 \%$ hingga $45 \%{ }^{26-28}$ Penelitian sebelumnya menunjukkan hasil yang serupa pada penelitian ini yaitu sekitar 71,9\% subyek memiliki tipe kulit IV. Melasma merupakan kelainan dengan perubahan lokal hiperpigmentasi yang umumnya muncul pada kulit tipe III-V. ${ }^{1}$

Beberapa penelitian menunjukkan peran penting faktor genetik dalam etiopatogenesis melasma. Adanya riwayat keluarga pada melasma dilaporkan bervariasi dari $20 \%$ hingga $70 \%$ pada beberapa penelitian yang berbeda. Sebagian besar (97\%) dari kasus anggota keluarga lain juga mengalami melasma pada kerabat tingkat pertama. ${ }^{29}$ Pada penelitian ini adanya riwayat keluarga dengan melasma didapatkan sekitar $65,6 \%$.

Faktor hormonal merupakan salah satu faktor utama dalam etiopatogenesis melasma ditunjukkan dari beberapa penelitian. Pada penelitian ini 18,9\% subyek menggunakan kontrasepsi hormonal yang terdiri atas $12,5 \%$ suntik dan $6,3 \%$ kontrasepsi oral. Ortonnne dkk. (2009) melaporkan bahwa 53\% dari 171 perempuan yang menderita melasma menggunakan kontrasepsi hormonal yang terdiri atas $87 \%$ kontrasepsi oral, $14 \%$ suntik dan $3,5 \%$ kontrasepsi tempel. ${ }^{29}$

Kadar sebum pada kulit lesi mengalami penurunan dibandingkan dengan kulit normal perilesi dan perbedaan pada keduanya bermakna secara statistik. Penelitian sebelumnya menunjukkan hasil yang serupa, kadar sebum pada kulit lesi lebih rendah dibandingkan kulit normal perilesi, namun tidak berbeda bermakna secara statistik. $^{20-22}$

Ekspresi gen terkait metabolisme lipid pada kulit lesi melasma dibandingkan kulit normal perilesi menunjukkan bahwa gangguan fungsi barier kulit berperan pada perkembangan melasma. ${ }^{30}$ Penelitian sebelumnya menunjukkan bahwa paparan radiasi UV kronis yang menjadi salah satu faktor penting pada etiopatogenesis melasma dapat memengaruhi metabolisme lipid dan fungsi barier kulit. ${ }^{31,32}$ Kim dkk. (2010) juga melaporkan hal yang serupa bahwa paparan radiasi UV dapat mengurangi asam lemak bebas epidermis dan sintesis trigliserida yang berperan penting pada homeostasis barier kulit. ${ }^{33}$ Foolad dkk. (2015) melaporkan penurunan sekresi sebum akibat paparan radiasi UV berperan pada perkembangan lesi melasma. Lipid pada sebum misalnya asam linoleik 
dapat menghambat melanogenesis, sehingga peningkatan sekresi sebum diduga dapat mencegah munculnya lesi melasma. ${ }^{34}$

Nilai TEWL mengalami peningkatan pada kulit lesi dibandingkan dengan kulit normal perilesi dan menunjukkan perbedaan yang bermakna secara statistik. Hidrasi kulit sebaliknya mengalami penurunan, namun tidak berbeda bermakna secara statistik antara kulit lesi dengan kulit normal perilesi. Penelitian Hua dkk. (2012) mendapatkan peningkatan nilai TEWL dan penurunan hidrasi kulit pada kulit lesi dibandingkan dengan kulit normal perilesi dan perbedaan ini bermakna secara statistik. ${ }^{20}$ Pada dua penelitian sebelumnya didapatkan bahwa pada kulit lesi melasma terjadi penipisan stratum korneum, hal ini diduga berkaitan dengan lambatnya proses pemulihan barier kulit. Ketebalan stratum korneum berbanding terbalik dengan TEWL. ${ }^{21,35}$

Secara umum, terdapat hubungan antara hidrasi kulit dengan nilai TEWL, semakin rendah nilai TEWL maka semakin normal hidrasi kulit. ${ }^{36}$ Peningkatan nilai TEWL diikuti oleh penurunan hidrasi kulit lesi melasma, namun penurunan ini tidak menunjukkan perbedaan yang bermakna antara kulit lesi dengan kulit normal perilesi. Penelitian Liu dkk. (2010) membuktikan bahwa paparan radiasi UV tidak menunjukkan perubahan bermakna hidrasi kulit area yang terpapar dibandingkan dengan area yang tidak terpapar. Fenomena ini belum dapat dijelaskan secara pasti, namun diduga hal tersebut berhubungan dengan besarnya dosis paparan radiasi $\mathrm{UV}^{37}$

Nilai $\mathrm{pH}$ kulit mengalami peningkatan pada kulit lesi dibandingkan dengan kulit normal perilesi, namun tidak berbeda bermakna secara statistik. Hasil ini sesuai dengan penelitian Rahrovan dkk. (2015) yang menunjukkan bahwa $\mathrm{pH}$ kulit secara bermakna meningkat pada kulit lesi dibandingkan dengan kulit normal perilesi. ${ }^{22}$ Lingkungan asam pada pemukaan kulit memiliki peran penting dalam mempertahankan homeostasis permeabili-

\section{DAFTAR PUSTAKA}

1. Handel AC, Miot LDB, Miot HA. Melasma: a clinical and epidemiological review. An Bras Dermatol. 2014;89:77182.

2. Kang HY, Ortonne JP. What should be considered in treatment of melasma. Ann Dermatol. 2010;22:373-8.

3. Sarkar R, Arora P, Garg VK, Sonthalia S, Gokhale N. Melasma update. Indian Dermatol Online J. 2014;5:426-35.

4. Tzouveka E. Epidemiology and risk factors of melasma. Pigmentary Disorders. 2014;S1:1-3.

5. Bagherani N, Gianfaldoni S, Smoller B. An overview on melasma. J Pigment Disord. 2015;2:1-18.

6. Rathi SK D'Souza P. Epidemiology melasma. Dalam: Lahiri K, Charttejee CM, Sarkar R, Penyunting. Pigmentary Disorders A Comprhensive Compedium. New Delhi: Jaypee Brother Medical. 2014: h.281-2. tas barier kulit, hal ini ditunjukkan dengan pentingnya mantel asam pada beberapa penyakit kulit. ${ }^{36}$ Penelitian sebelumnya membuktikan bahwa asidifikasi merupakan faktor penting pada permeabilitas barier karena proses pemulihan barier normalnya dimulai pada $\mathrm{pH}$ asam. Gagalnya proses pemulihan barier disebabkan adanya gangguan proses sintesis lipid ekstraselular pada stratum korneum. $^{38}$

Pada penelitian ini didapatkan bahwa tidak ada korelasi antara fungsi barier kulit lesi baik berdasarkan nilai TEWL, kadar sebum, hidrasi maupun $\mathrm{pH}$ kulit dengan skor MASI pada pasien melasma. Hal ini mungkin disebabkan karena skor MASI yang kurang bervariasi, tidak dijumpai skor MASI yang termasuk kategori berat pada penelitian ini. Hasil uji korelasi ini belum bisa dibandingkan dengan penelitian lain, dikarenakan penelitian yang meneliti korelasi antara fungsi barier kulit lesi dengan skor MASI belum pernah dilaporkan.

Kelemahan lain pada penelitian ini yaitu tidak dapat menjelaskan hubungan sebab akibat antara fungsi barier kulit dengan melasma. Penelitian ini merupakan penelitian pertama yang meneliti fungsi barier kulit pada pasien melasma di Indonesia. Penelitian lebih lanjut diperlukan untuk dapat melengkapi hasil dari penelitian ini, mungkin sebaiknya menggunakan metode rancangan yang berbeda. Metode rancangan penelitian yang dapat dipertimbangkan antara lain berupa kasus kontrol ataupun kohort.

\section{SIMPULAN}

Kesimpulan dari penelitian ini adalah terdapat perbedaan fungsi barier berdasarkan TEWL, kadar sebum, dan $\mathrm{pH}$ kulit, namun tidak terdapat perbedaan fungsi barier berdasarkan hidrasi kulit antara kulit lesi dengan kulit normal perilesi pada pasien melasma. Tidak terdapat korelasi antara fungsi barier kulit lesi dengan skor MASI pada pasien melasma.

7. Denda M. Skin barrier function as a self-organizing system. Forma. 2000;15:227-32.

8. Baroni A, Buommino E, Gregorio VD, Ruocco E, Ruocco $\mathrm{V}$, Wolf R. Structure and function of the epidermis related to barrier properties. Clin Dermatol. 2012;30:257-62.

9. Elias PM, Menon G, Wetzel BK, Williams J. Evidence that stress to the epidermal barrier influenced the development of pigmentation in humans. Pigment Cell Melanoma Res. 2009;22:420-34.

10. Elias PM, Menon G, Wetzel BK, Williams J. Barrier requirements as the evolutionary "driver" of epidermal pigmentation in humans. Am J Hum Biol. 2010;22:526-37.

11. Biniek K, Levi K, Dauskardt RH. Solar UV radiation reduces the barrier function of human skin. Proc Natl Acad Sci U S A. 2012;109:17111-6. 
12. Menon GK. Skin basics; structure and function. Dalam: Pappas A., Penyunting. Lipids and skin health. Springer: Switzerland. 2015: h.9-18.

13. Hirobe T. Role of keratinocyte-derived factors involved in regulating the proliferation and differentiation of mammalian epidermal melanocytes. Pigment Cell Res. 2004;18:2-12.

14. Yamaguchi Y, Hearing VJ. Physiological factors that regulate skin pigmentation. Biofactors. 2009;35:193-9.

15. Elias PM, Williams ML. Re-appraisal of current theories for the development and loss of epidermal pigmentation in hominins and modern humans. J Hum Evol. 2013;64:68792.

16. Man MQ, Lin TK, Santiago JL, Celli A, Zhong L, Huang $\mathrm{ZM}$, dkk. Basis for enhanced barrier function of pigmented skin. J Invest Dermatol. 2014;134:2399-407.

17. Im S, Kim J, On WY, Kang WH. Increased expression of alpha-melanocyte-stimulating hormone in the lesional skin of melasma. Br J Dermatol. 2002;146:165-7.

18. Bak H, Lee HJ, Chang SE, Choi JH, Kim MN, Kim BJ. Increased expression of nerve growth factor receptor and neural endopeptidase in the lesional skin of melasma. Dermatol Surg. 2009;35:1244-50.

19. Kim EJ, Chang SE, Yeo UC, Haw S, Kim IH. Histopathological study of the treatment of melasma lesions using a low-fluence Q-switched 1064-nm neodymium:yttrium-aluminium-garnet laser. Clin Exp Dermatol. 2013;38:167-71.

20. Hua J, Wen L, Fu-Hua L, Li H. The application of non-invasive physiometry in different clinical type of melasma and its clinical significance. J Dermatol Venereol. 2012;76:6970.

21. Lee DJ, Lee J, Ha J, Park KC, Ortonne JP, dkk. Defective barrier function in melasma skin. JEADV. 2012;26:1533-7.

22. Rahrovan S, Hasanzadeh H, Khodakarim S, Firooz A. Biophysical characteristics of melasma skin comparing with the perilesional normal skin and its relation to the melasma subtype. Pigmentary Disorders. 2015;2:1-4

23. Sarvjot V, Sharma S, Mishra S, Singh A. Melasma: a clinicopathological study of 43 cases. Indian J Pathol Microbiol. 2009;52:357-9.

24. Cestari TF, Dantas LP, Boza JC. Acquired hyperpigmentations. An Bras Dermatol. 2014;89:11-25.

25. Sonthalia S, Sarkar R. Etiopathogenesis of melasma. Pigment Int. 2015;2:21-7.
26. Tamega AA, Miot LD, Bonfietti C, Gige TC, Marques ME, Miot HA. Clinical patterns and epidemiological characteristics of facial melasma in Brazilian women. JEADV. 2013;27:151-6.

27. Guinot C, Cheffai S, Latreille J, Dhaoui MA, Youssef S, Jaber K, dkk. Aggravating factors for melasma: a prospective study in 197 Tunisian patients. JEADV. 2010;24:1060-9.

28. Hexsel D, Lacerda D A, Cavalcante AS, Machado FCA, Kalil CL, Ayres, EL, dkk. Epidemiology of melasma in Brazilian patients: a multicenter study. Int J Dermatol. 2013;53:440-4.

29. Ortonne JP, Arellano I, Berneburg M, Cestari T, Chan H, Grimes P, dkk. A global survey of the role of ultraviolet radiation and hormonal influences in the development of melasma JEADV. 2009;23:1254-62.

30. Kang HY, Suzuki I, Lee DJ, Ha J, Reiniche P, Aubert J, dkk. Transcriptional profiling shows altered expression of Wnt pathway- and lipid metabolism-related. genes as well as melanogenesis-related genes in melasma. J Invest Dermatol. 2011;131:1692-700.

31. Feingold KR. The role of epidermal lipids in cutaneous permeability barrier homeostasis. J Lipid Res. 2007;48:253146.

32. Merle C, Laugel C, Baillet-Guffroy A. Effect of UVA or UVB irradiation on cutaneous lipids in films or in solution. Photochem Photobiol. 2010;86:553-62.

33. Kim EJ, Jin XJ, Kim YK, Oh IK, Kim JE, Park CH, dkk. UV decreases the synthesis of free fatty acids and triglycerides in the epidermis of human skin in vivo contributing to development of skin photoaging. J Dermatol Sci. 2010;57:19-26.

34. Foolad N, Shi V, Prakash N, Kamangar F, Sivamani RK. The association of the sebum excretion rate with melasma, erythematotelangiectatic rosacea, and rhytides. Dermatol Online J. 2015;21:2.

35. Kang WH, Yoon KH, Lee ES, Kim J, Lee KB, Yim H, dkk. Melasma: histopathological characteristics in 56 Korean patients. Br J Dermatol. 2002;146:228-37.

36. Darlenski R, Sassning S, Tsankov N, Fluhr JW. Non-invasive in vivo methods for investigation of the skin barrier physical properties. Eur J Pharm Biopharm. 2009;72:295-303.

37. Liu Z, Fluhr JW, Song SP, Sun Z, Wang H, Shi YJ, dkk. Suninduced changes in stratum corneum function are gender and dose. Dependent in a Chinese Population. Skin Pharmacol Physiol. 2010;23:313-9.

38. Mauro T, Holleran WM, Grayson S, Gao WN, Man MQ, Kriehuber E, dkk. Arch Dermatol Res. 1998;290:215-22. 